\title{
ANALISIS KEBUTUHAN DIKLAT PEGAWAI NEGERI SIPIL BERBASIS KESENJANGAN KERJA UNIT KERJA DI LINGKUNGAN PEMERINTAH KOTA MOJOKERTO
}

\author{
Rispa Ngindana1, Romy Hermawan² \\ ${ }^{1}$ Universitas Brawijaya Malang \\ email: rispangindana@ub.ac.id \\ ${ }^{2}$ Universitas Brawijaya Malang \\ email: romy@ub.ac.id
}

\begin{abstract}
ABSTRAK
Tuntutan akan produktifitas organisasi semakin tinggi baik profit maupun non-profit secara otomatis harus mampu mengadapi komplekitas lingkungan. Demikian halnya organisasi pemerintah baik di pusat maupun di daerah, kinerjanya dituntut untuk selalu dapat melayani masyarakat beserta segala komplekitas kebutuhannya sebagai koteks lingkungannya. Kinerja organisasi dapat dikatakan sebagai akumulasi dari kinerja individuindividu yang bekerja sama di dalamnya. Begitu pula dengan kinerja organisasi pemerintahan yang tidak bisa lepas dari kinerja Pegawai Negeri Sipil (PNS) sebagai individu-individu di dalamnya. Kondisi tersebut menunjukan bahwa kompetensi PNS di Indonesia menjadi masalah yang perlu mendapatkan perhatian serius. Salah satu upaya yang dapat ditempuh dalam mengatasi permasalahan kompetensi PNS yakni melalui pendidikan dan pelatihan (Diklat). Penelitian ini bertujuan mengidentifikasi tentang adanya kebutuhan dalam hal peningkatan kinerja maupun kompetensi PNS di Lingkungan Pemerintah, menentukan kebutuhan Diklat PNS, dan memberikan rekomendasi program Diklat sebagai solusi untuk memenuhi kebutuhan dalam upaya peningkatan kemampuan PNS di Lingkungan Pemerintah. Peneliti melakukan wawancara, survey dan observasi terhadap Pegawai Aperatur Sipil Negara (ASN) di lingkungan pemerintah kota Mojokerto. Berdasarkan analisis yang dilakukan diketahui bahwa Setiap Unit Kerja memiliki karakteristik masing-masing sesuai dengan tugas dan fungsinya. Pada level jabatan struktural juga memeiliki kebutuhan diklat yang dapat diusulkan secara individu sesuai pangkat dan jabatan.
\end{abstract}

Kata Kunci: analisis kebutuhan, diklat, kesenjangan kerja

\section{PENDAHULUAN}

Seiring berkembangnya zaman, tuntuan akan produktivitas organisasi juga semakin tinggi. Apapun jenis organisasinya baik profit maupun non-profit secara otomatis harus mampu mengadapi komplekitas lingkungan. Demikian halnya organisasi pemerintah baik di pusat maupun di daerah, kinerjanya dituntut untuk selalu dapat melayani masyarakat beserta segala komplekitas kebutuhannya sebagai koteks lingkungannya. Kinerja organisasi dapat dikatakan sebagai akumulasi dari kinerja individu-individu yang bekerja sama di dalamnya. Begitu pula dengan kinerja organisasi pemerintahan yang tidak bisa lepas dari kinerja Pegawai Negeri Sipil (PNS) sebagai individu-individu di dalamnya.

Berkaitan dengan kinerja PNS, beberapa penelitian menunjukkan bahwa terdapat suatu keterkaitan yang kuat antara kinerja pegawai dengan kompetensi pegawai. Seperti 
penelitian yang dilakukan Emmyah (2009) di Politeknik Negeri Ujung Pandang menunjukkan bahwa kompetensi pegawai memberikan pengaruh yang signifikan terhadap kinerja pegawai. Selain itu juga penelitian Adiputra (2011) di Kantor Pelayanan Pajak Pratama Badung Selatan yang menunjukkan bahwa terdapat hubungan yang kuat antara kompetensi dengan kinerja pegawai. Berdasarkan hal tersebut dapat diketahui bahwa kinerja PNS juga ditentukan oleh kompetensi PNS yang bersangkutan sesuai dengan tugas dan wewenangnya masing-masing.

Perlu diketahui bahwa kompetensi PNS di Indonesia masih mengalami permasalahan. Seperti yang diungkapkan mantan Menteri Pemberdayaan Aparatur Negara dan Reformasi Birokrasi, Azwar Abubakar pada 2012 silam bahwa Indonesia mengalami krisis PNS yang kompeten. Sebanyak 4,7 juta PNS di Indonesia, 95\% diantaranya tidak memiliki kompetansi di bidangnya (Hartawan dalam http://nasional.tempo.co/, 2012). Hal yang senada juga muncul dari pakar Manajemen dan Kebijakan Publik Fisipol Universitas Gajah Mada dan Lembaga Administrasi Negara (LAN), Agus Dwiyanto. Permasalahan PNS di Indonesia ini bukan semata-mata pada kuantitas yang terlalu besar, melainkan lebih mandasar pada kualitas yakni kompetensi yang sangat minim (Prayoga dalam http://www.antaranews.com/, 2015).

Kondisi tersebut menunjukan bahwa kompetensi PNS di Indonesia menjadi masalah yang perlu mendapatkan perhatian serius. Salah satu upaya yang dapat ditempuh dalam mengatasi permasalahan kompetensi PNS yakni melalui pendidikan dan pelatihan (Diklat). Sebagaimana Hafid yang mempublikasikan sebuah kajian yang menunjukkan bahwa Diklat dapat dijadikan alternatif dalam sebuah upaya pengembangan kompetensi PNS (Hafid, 2015 dalam http://makassar.lan.go.id/). Hal yang serupa juga ditemukan dalam penelitian yang dilakukan Helena (2009), hasil menunjukkan bahwa terdapat hubungan positif, kuat, dan signifikan antara Diklat Kepemimpinan Tk. IV dengan kompetensi PNS di Lingkungan Pemerintah Kabupaten Aceh Tamiang (Helena, 2009). Ministry of Interior and Japan International Cooperation Agency (JICA) dalam buku panduan TNA, memberikan pernyataan bahwa Diklat itu dibutuhkan karena untuk memastikan PNS memiliki pengetahuan dan kemampuan yang tepat untuk dapat mengerjakan tugasnya dengan efektif dan kompeten (Ministry of Interior and JICA).

Secara normatif keseriusan pemerintah terhadap penyelenggaraan Diklat PNS dapat dilihat sejak munculnya Peraturan Pemerintah Republik Indonesia Nomor 101 Tahun 2000 Tentang Pendidikan dan Pelatihan Jabatan Pegawai Negeri Sipil. Secara kelembagaan, Pendidikan dan Pelatiahn (Diklat) PNS telah dibentuk Badan Kepegawaian Negara. Lembaga ini berfungsi sebagai pengendali yang bertanggung jawab atas pengembangan dan pengawasan standar kompetansi jabatan serta pengendalian pemanfaatan lulusan Diklat. Selain itu terdapat instansi pembina Diklat yakni, Lembaga Administrasi Negara (LAN) yang bertanggung jawab atas pengaturan, koordinasi, dan penyelenggaraan Diklat.

Kendati demikian tidak serta merta Diklat PNS yang sejauh ini dilakukan di Indonesia menghadapi permasalahan. Seperti yang diketahui bahwa permasalahan yang terjadi pada Diklat PNS yakni mengenai ketidaksesuaian antara Diklat yang diselenggarakan dengan kebutuhannya. Sebagaimana Saleh et.al (2013) menegaskan bahwa berbagai Diklat yang dilakukan pada PNS sebagian besar tidak memiliki relevansi terhadap jenis dana bentuk tugas pekerjaan yang mereka emban. Hal yang demikian menunjukkan Diklat PNS yang dilakukan tidak memberikan kontrbusi pada organisasinya.

Mengingat masih adanya permasalahan yang menjangkiti penyelanggaraan Diklat

PNS di Indonesia nampaknya perlu ada formula yang tepat untuk memperbaiki penyelanggaraan Diklat PNS. Terdapat suatu metode yang dapat dijadikan sebuah solusi atas permasalahan penyelanggaraan Diklat yang tidak sesuai dengan kebutuhannya. 
Konsep tersebut dikenal dengan Analisis Kabutuhan Diklat (AKD) atau yang dikenal di dunia internasional sebagai Tranining Needs Analysis (TNA). Secara umum yang melandasi dibutuhkannya AKD yakni untuk mengidentifikasi kesenjangan yang terdapat diantara kondisi saat ini dengan kondisi yang diinginkan atau kesenjangan antara das sein dengan das solen. Selanjutnya, terdapat empat poin utama yang menurut Brown (2002) menjadi alasan perlu dilakukannya AKD sebelum menyusun program Diklat, antara lain untuk mengidentifikasi permasalahan spesifik dalam organisasi, untuk memperoleh dukungan dalam manajemen, untuk menghasilkan data sebagai bahan evaluasi, serta untuk menentukan keuntungan dan kerugian dari sebuah Diklat.

Oleh karena itu dalam konteks Diklat PNS, mindset harus selalu difokuskan pada suatu kaidah bahwa langkah paling utama dalam penyusunan program Diklat PNS adalah kegiatan Analisis Kebutuhan Diklat (AKD). AKD memiliki memiliki kaitan yang sangat erat dengan perencanaan Diklat. Kebutuhan Diklat dapat dilihat dengan membandingkan antara tingkat kompetansi yang diharapkan dengan tingkat kompetensi yang saat ini dimiliki oleh PNS. Berdasarkan hal tersebut dan beberapa fakta teoritis maupun empiris yang telah dipaparkan di atas, dapat diambil sebuah arti penting bahwa AKD PNS mutlak diperlukan. Hal ini bertujuan untuk mewujudkan efektivitas dan efisiensi suatu Diklat guna mendukung peningkatan kompetensi PNS di Indonesia yang pada akhirnya bermuara pada peningkatan kinerja dan produktifitas organisasi pemerintah di Indonesia. Pelaksanaan AKD PNS tentu tidak bisa terlepas dari dukungan pemerintah daerah. Sebagai wujud desentralisasi kepegawaian, maka pemerintah daerah sudah saatnya melaksanakan AKD sebagai dasar acuan dalam penyelenggaraan program Diklat PNS.

Dalam penelitian ini akan mengamati kondisi terkait akan kinerja maupun kompetensi, kebutuhan Diklat dan jenis Diklat yang tepat untuk memenuhi kebutuhan Diklat PNS di Lingkungan Pemerintahan Kota Mojokerto. Sehingga bias mengindentifikasi akan kebutuhan dalam hal peningkatan kinerja maupun kompetensi, menentukan kebutuhan Diklat dan menentukan jenis Diklat yang memenuhi kebutuhan Diklat PNS di Lingkungan Pemerintah Kota Mojokerto.

\section{TINJAUAN PUSTAKA}

\section{Manajemen Sumber Daya Aparatur Sipil Negara (ASN)}

\section{a. Pengertian Manajemen ASN}

Konsep Manajemen Aparatur Sipil Negera (ASN) pada intinya diadasarkan pada sebuah konsep besar yakni, manajemen sumber daya manusia (MSDM), namun dikontekstualisasikan ke dalam ranah profesi manusia sebagai Aparatur Sipil Negara (ASN). Oleh karena itu dalam bagian ini akan dipaparkan pengertian MSDM yang dikemukakan oleh beberapa ahli. Hasibuan (2002) memberikan penjelasan bahwa MSDM adalah suatu ilmu dan seni mengatur hubungan dan peranan tenaga kerja agar efektif dan efisien untuk membantu terwujudnya tujuan perusahaan, pegawai, dan masyarakat. Douglas \& Goodale (1986: 6) menjelaskan bahwa MSDM adalah suatu proses penyesuaian secara optimal antara pegawai, pekerjaan dan lingkungan organisasi sehingga para pegawai mencapai tingkat kepuasan dan performansi yang mereka inginkan dan organisasi memenuhi tujuannya.

Selanjutnya, Barthos (1990) menyatakan bahwa MSDM timbul sebagai suatu masalah baru pada dasaarsa 1960-an. MSDM mencakup masalah-masalah yang berkaitan dengan pembinaan, penggunaan, dan perlindungan sumbersumber daya manusia baik yang berada dalam hubungan kerja maupun yang berusaha sendiri. Tunggal (1990) mengemukakan bahwa MSDM adalah fungsi 
manajemen yang berhubungan dengan rekrutmen, penempatan, pelatihan, dan pengembangan anggota organisasi. Menurut Handoko (2001), MSDM meliputi kegiatan penarikan, seleksi, pengembangan, pemeliharaan, dan penggunaan sumber daya manusia untuk mencapai baik tujuan-tujuan individu maupun organisasi.Berdasarkan penjelasan beberapa ahli tersebut dapat disimpulkan bahwa manajemen sumber daya manusia (MSDM) merupakan kegiatan pengelolaan SDM yang meliputi rekrutmen yang termasuk didalamnya kegiatan penarikan dan seleksi sumber daya manusia (rekrutmen), pembinaan, pelatihan, pemeliharaan/perlindungan, pengembangan, dan penggunaan sumber daya manusia. peraturan perundang-undangan juga telah mengatur manajemen ASN, termasuk di dalamnya Manajemen PNS dan juga Manajemen PPPK yang termuat dalam UU No. 5 Tahun 2014 tentang ASN. Perlu diketahui bahwa manajemen ASN di Indonesi berdasarkan peraturan perundang-undangan tersebut telah menganut sistem merit, artinya kebijakan dan manajeman ASN berdasarkan kepada kualifikasim kompetensi, dan kinerja secara adil dan wajar dengan tanpa membedakan latar belakang politik, ras, warna kulit, agama, asal usul, jenis kelamin, status pernikahan, umur, atau kondisi kecacatan.

\section{b. Fungsi Manajemen ASN}

Kegiatan pengelolan SDM dalam suatu organisasi memiliki fungsi pokok yang sama dalam fungsi manajemen. Fungsi yang diterapakan pada bidang SDM sebagaimana dijelaskan oleh Arep dan Tanjung (2002).

\section{c. Tujuan Manajemen ASN}

Manajemen ASN yang pada dasarnya merupaka suatu kegiatan Manajemen Sumber Daya Manusia (MSDM) dalam konteks pemerintahan. Merujuk penjelasan Sofiyandi (2008) MSDM ini memiliki tujuan umum yakni sebagai penyeimbang tantangan-tantangan yang dihadapi oleh organisasi yang meliputi fungsi-fungsi manajemen sumberdaya manusia, masyarakat,dan karyawan yang dipengaruhi oleh tantangan-tantangan tersebut. Sedangkan tujuan khususnya meliputi organisasional, fungsional, sosial dan personal.

\section{Uraian Pekerjaan}

Uraian pekerjaan adalah informasi tertulis yang menguraikan tugas dan tanggung jawab, kondisi pekerjaan, hubungan pekerjaan, dan aspek-aspek pekerjaan pada suatu jabatan tertentu dalam organisaasi (Arep dan Tanjung, 2002). Uraian pekerjaan ini menjadi dasar untuk menetapkan spesifikasi pekerjaan dan evaluasi pekerjaan bagi pejabat yang memegang jabatan itu. Uraian pekerjaan yang kurang jelas akan mengakibatkan seorang pejabat kurang mengetahui tugas dan tanggung jawabnya. Hal ini mengakibatkan pekerjaan tidak beres. Di sinilah letak pentingnya uraian pekerjaan dalam setiap organisasi. Menurut Dessler (2006), uraian pekerjaan adalah pernyataan tertulis tentang apa yang sebenarnya dilakukan oleh pekerja, bagaimana orang itu melakukannya, dan bagaimana kondisi kerjanya.

\section{Pendidikan dan Pelatihan}

Menurut Suwatno dan Rasto (2003), mengemukakan bahwa pendidikan dan pelatihan memberikan bantuan kepada karyawan agar dapat meningkatkan kemampuan kerja dan menumbuhkan pengertian tentang status dirinya dan tujuan perusahaan. Perbedaan antara pendidikan dan pelatihan yang sering kita pahami yaitu pendidikan merupakan upaya untuk meningkatkan pengetahuan umum dan sikap pegawai dan lebih banyak menekankan pada teori. Sedangkan pelatihan merupakan 
kegiatan untuk meningkatkan kecakapan. Pelatihan lebih banyak menekankan pada kegiatan praktik.

Notoatmodjo (2003), mengemukakan bahwa pendidikan dan pelatihan adalah suatu proses yang akan menghasilkan suatu perubahan perilaku sasaran pendidikandan pelatihan. Secara konkret perubahan perilaku itu berbentuk peningkatankemampuan dari sasaran pendidikan dan pelatihan. Kemampuan ini mencakupkognitif, afektif, maupun psikomotor. Apabila dilihat dari pendekatan sistem, makaproses pendidikan dan pelatihan itu terdiri dari input (sasaran diklat) dan output(perubahan perilaku), dan faktor yang mempengaruhi proses tersebut.

Menurut Simamora (1995), pelatihan adalah serangkaian aktivitas yang dirancang untuk meningkatkan keahlian-keahlian, pengetahuan, pengalaman, ataupun perubahan sikap seorang individu. Pelatihan merupakan penciptaan suatu lingkungan dimana para karyawan dapat memperoleh atau mempelajari sikap, kemampuan, keahlian, pengetahuan dan perilaku yang spesifik yang berkaitan dengan pekerjaan. Dengan demikian pelatihan sangat berkaitan dengan upaya mendapatkan keahlian, pengalaman dan pengetahuan tertentu yang dapat membatu trainee dalam melaksanakan pekerjaannya.

Pendidikan dan pelatihan adalah unsur utama dalam mengembangkan kemampuan pegawai. Kegiatan pendidikan diberikan untuk meningkatkan pengetahuan yang akan meningkatkan kinerja pegawai. Desain pelatihan yang sangat kompleks diberikan untuk membantu pegawai dalam mempelajari keterampilan baru yang akan meningkatkan kinerja mereka. Pegawai yang terampil dan berkompetensi sesuai dengan tugas daan pekerjaannya akan mampu membantu organisasi mencapai tujuan dan sasarannya.

\section{Analisis Kebutuhan Diklat/Training Need Analysis (TNA)}

\section{a. Pengertian Analisis Kebutuhan Diklat/Training Need Analysis (TNA)}

Seperti yang telah dijelaskan pada bagian sebelumnya, bahwa analisis kebutuhan diklat atau yang juga dikenal dengan Training Need Analysis (TNA) merupakan tahapan pertama yang perlu dilakukan sebelum mengadakan rogram maupun kegiatan pendidikan dan pelatihan. Menurut Mangkunegara (2003), Training Need Analysis (TNA) adalah suatu studi sistematis tentang suatu masalah pendidikan dengan pengumpulan data dan informasi dari berbagai sumber, untuk mendapatkan pemecahan masalah atau saran tindakan selanjutnya. Informasi kebutuhan diklat yang dihasilkan ini akan membantu perusahaan untuk menentukan prioritas jenis diklat yang akan dilakukan, sehingga akan membantu perusahaan dalam menentukan jadwal, anggaran dan sumber daya lainnya. Hal ini juga dapat dilakukan untk meminimalisir diklat-diklat yang tidak diperlukan.

Analisis kebutuhan pelatihan adalah suatu diagnosa untuk menentukan masalah yang dihadapi saat ini dan tantangan di masa mendatang yang harus dihadapi saat ini dan tantangan di masa mendatang yang harus dipenuhi oleh program pelatihan dan pengembangan (Rivai dan Sagala.2009). Hariandja (2007), mengemukakan analisis kebutuhan pelatihan dan pengembangan sangat penting, rumit, dan sulit. Sangat penting sebab di samping menjadi landasan kegiatan selanjutnya seperti pemilihan metode pelatihan yang tepat, biaya pelatihannya tidak murah, sehingga apabila pelatihan tidak sesuai dengan kebutuhan, selain tidak meningkatkan kemampuan organisasi juga akan menghabiskan banyak biaya. Selanjutnya dikatakan rumit dan sulit sebab perlu mendiagnosis kompetensi organisasi pada saat ini dan kompetensi yang 
dibutuhkan sesuai dengan kecenderungan perubahan situasi lingkungan yang sedang dihadapi dan yang akan dihadapi pada masa yang akan datang.

b. Kondisi Diperlukannya Analisis Kebutuhan DIklat/Training Need Analysis (TNA)

Kondisi diperlukannya TNA bagi suatu organisasi sangat beraneka ragam, namun dalam hal ini kondisi dimana diperlukan suatu TNA adalah sebagai berikut:

1) Adanya ketidaksesuaian antara standar kinerja yang sudah ditentukan dengan kinerja dan prestasi kerja pegawai yang disebabkan oleh faktor internal muapun eksternal pegawai itu sendiri.

2) Adanya kebijakan baru dari organisasi baik dalam hal sasaran, produk baru yang dihasilkan dan pasar baru yang menjadi tujuan.

3) Adanya struktur kerja baru sebagai upaya pemekaran atau perampingan usaha.

4) Adanya kebijakan modernisasi dibidang manajemen, sarana dan prasarana.

5) Adanya undang-undang maupun peraturan pemerintah baru yang menuntut perubahan pada organisasi.

\section{c. Tujuan dan Fungsi Analisis Kebutuhan Analisis Kebutuhan DIklat/Training} Need Analysis (TNA)

Tujuan dari analisis kebutuhan menurut Panggabean (2004), antar lain:

$>$ Mengindentifikasi keterampilan prestasi kerja khusus yang dibutuhkan untuk memperbaiki kinerja dan produktivitas.

$>$ Menganalisis karakteristik peserta untuk menjamin bahwa program tersebut cocok untuk tingkat pendidikan, pengalaman, dan keterampilan begitu jugasikap dan motivasi seseorang.

$>$ Mengembangkan pengetahuan khusus yang dapat diukur dan objektif. Dalam tahap ini harus ada keyakinan bahwa penurunan kinerja dapat ditingkatkan melalui pelatihan dan bukan disebabkan ketidakpuasan terhadap kompensasi.

\section{d. Training Need Assesment Tool (TNA-T)}

Menurut Arep dan Tanjung (2002), metode Training Need Assesment Tool (TNA-T) digunakan untuk menganalisis kesenjangan Kemampuan Kerja Jabatan (KKJ) dan Kemampuan Kerja Pribadi (KKP) pegawai, yaitu kemampuan kerja yang dimiliki seorang pegawai dalam melakukan pekerjaan yang ditugaskan kepadanya. Keunggulan metode TNA-T ini adalah memperkecil subjektifitas penilaian, sedangkan kelemahannya adalah bias. Hal ini disebabkan oleh yang dinilai tidak memberikan informasi yang jujur (sebenarnya).

Apabila ditemukan selisih antara KKJ dengan KKP maka solusinya adalah dilakukan pelatihan. Kesenjangan ini muncul karena rendahnya pengetahuan, sikap dan keterampilan pegawai. Untuk mempermudah dalam memahami konsep tersebut, berikut ini adalah rumus dalam TNA-T:

$\begin{array}{lll}\text { KKJ }- \text { KKP } & = & \text { Kekurangan kemampuan kerja yang perlu dilatih } \\ \text { KKP + Pelatihan } & = & \text { KKJ } \\ \text { Pelatihan } & = & \begin{array}{l}\text { Mengatasi kekurangan kemampuan kerja yang } \\ \text { memerlukan pelatihan }\end{array}\end{array}$


Kebutuhan pelatihan sesuai dengan konsep diatas dapat dilakukan penelaahan melalui dua instrument berikut ini:

$>$ Instrumen 1 : Mengukur performance capability

$>$ Instrumen 2 : Menafsirkan data performance capability.

\section{METODE}

Jenis penelitian yang digunakan dalam analisis kebutuhan pendidikan dan pelatihan pegawai negeri sipil ini tergolong dalam penelitian terapan. Data yang digunakan dalam penelitian ini adalah data primer yang mana seluruh jajaran Pegawai Aperatur Sipil Negara di lingkungan Pemerintahan Kota Mojokerto sebagai informan dan data sekunder sebagai pendukung yang didapat dari berbagai sumber baik dari media cetak maupun media online dan dokumen-dokumen yang terkait dengan yang berasal dari lingkungan Pemerintahan Kota Mojokerto.

\section{HASIL DAN PEMBAHASAN}

Pembahasan. Analisis Kebutuhan Diklat dilakukan dengan membandingkan antara capaian kinerja actual dengan standar kinerja yang telaah ditetapkan. Sebagaimana kita ketahui bahwa yang dimaksud dalam kebutuhan pada analisis kebutuhan diklat ini adalah kesenjangan kinerja. Kesenjangan kinerja dalam hal ini adalah perbedaan antara perbuatan, pengetahuan, dan perasaan dengan apa yang seharusnya diperbuat, seharusnya diketahui dan seharusnya dirasakan. Perbuatan, pengetahuan, dan perasaan tersebut merupakan suatu kemampuan yang dimiliki oleh pegawai itu sendiri. Oleh karena itu kebutuhan dapat diketahui dari adanya kondisi belum tercapainya suatu situasi berdasarkan ketentuan kerja yang dipersyaratkan bagai suatu jabatan dalam organisasi. Beberapa potensi yang memunculkan kesenjangan antara kinerja aktual dan standar kinerja di Pemerintah Kota Mojokerto ini adalah:

a. Pegawai baru.

Pegawai baru yang dimaksud disini adalah pegawai baru karena proses rekruitmen, mutasi dan promosi. Pegawai baru dengan sebab tersebut sering mengalami kekurangan pemahaman terhadap tugas barunya;

b. Kebijakan Baru. Kebijakan ini berimplikasi pada perubahan standar kinerja baik itu prosedur maupun penambahan tanggung jawab baru;

c. Usia produktif kerja. Usia ini berpengaruh terhadap pencapaian target kinerja pegawai.

d. Perubahan Strategi Organisasi.

Perubahan ini memiliki konsekuensi terhadap perubahan proses pencapaian tujuan unit kerja dan kualifikasi SDM yang diperlukan.

e. Implementasi konsep the right man on the right place yang belum maksimal dikarenakan masih adanya penerapan spoil system recruitment dan belum adanya SDM yang sesuai dengan kebutuhan jabatan di beberapa unit kerja.

Dalam melakuakan analisis kesenjangan kerja diperluken proses identifikasi akar masalah dari kesenjangan antara kinerja yang diharapkan dengan kinerja yang sesungguhnya. Berikut adalah sebab-sebab munculnya kesenjangan kinerja:

1. Tidak adanya kesempatan bagi pegawai untuk melakukan tugas.

2. Tidak adanya kemauan dan kemampuan pagawai dalam melaksanakan tugas.

3. Tidak adanya pengetahuan terkait dengan tata cara mengerjakan tugas. 
Akar permasalahan kesenjangan kinerja yang terjadi pada Unit Kerja di Pemerintah Kota Mojokerto adalah sebagai berikut:

a. Faktor individu

$>$ Kemampuan dan keterampilan

> Latar belakan pendidikan

$>$ Demografi (jenis kelamin,usia, ras dan keragaman budaya)

Dari hasil penelitian yang dilakukan pegawai perempuan memiliki tingkat absensi yang lebih tinggi. Hal ini disebabkan karena perempuan memiliki peran mengasuh lebih pada anak-anak, orang tua, dan pasangannya sakit.

b. Faktor psikologis

$>$ Persepsi

$>$ Sikap

$>$ Kepribadian

$>$ Motivasi

$>$ Kepuasan Kerja

c. Tidak terimplementasikannya dengan baik prinsip the right man on the right place.

Hasil. Identifikasi Kebutuhan Diklat berbasis kesenjangan kerja unit kerja ini merupakan suatu proses untuk mengidentifikasi kesenjangan antara kinerja aktual dengan standar kinerja, dan identifikasi akar permasalahan kesenjangan. Dari hasil identifikasi tersebut maka dapat diambil keputusan jenis-jenis Diklat yang dibutuhkan oleh Unit Kerja pengguna Diklat. Jenis diklat yang diputuskan berdasarkan identifikasi tersebut akan menghasilkan jenis diklat yang bersifat untuk pengembangan organisasi, jabatan, maupun individu.

Keberadaan hasil analisis kebutuhan diklat ini akan dapat memudahkan penyelenggara atau pengelola Diklat dalam menentukan program-program Diklat yang dibutuhkan oleh Unit Kerja pengguna Diklat. Proses identifikasi kebutuhan diklat merupakan suatu proses yang mutlak dilaksanakan.

Tabel 2. Rekomendasi Kebutuhan Diklat

\begin{tabular}{ccrl}
\hline No & SKPD & & \multicolumn{1}{c}{ Kebutuhan Diklat } \\
\hline $\mathbf{1}$ & Kec. Magersari & 1) & Diklat standart operasional prosedur (SOP) \\
& & 2) & Bintek Penyusunan Laporan Keuangan Instansi Pemerintahan \\
& & 3) & Bintek nasional management komunikasi publik dalam rangka \\
& & peningkatan citra organisasi \\
& & 4) & Bintek penilaian prestasi kerja PNS dan penyusunan SKP \\
& & 5) & Project Management Knowledge \\
\hline $\mathbf{2}$ & Dinas Sosial & 1) & Diklat Pelatihaan Pekerja Sosial \\
& & 2) & Bintek sistem administrasi kepegawaian \\
\hline $\mathbf{3}$ & Dishubkominfo & 3) & Pelatihan Pekerja Sosial \\
& & 2) & Diklat pengangkatan arsiparis tingkat terampil \\
& & 3) & Bintek sistem administrasi kepegawaian \\
& & 4) & Diklat penyusunan renstra dan renja SKPD (BAPEKO) \\
& & 5) & Diklat analisa lalu lintas \\
\hline $\mathbf{4}$ & Satpol PP & 1) & Diklat Standart Operasional Prosedur (SOP) \\
& & 2) & Diklat Satpol PP \\
& 3) & Diklat PPNS \\
\hline
\end{tabular}


4) Diklat Administrasi pemerintah

5) Diklat Aparatur Sipil Negara

\begin{tabular}{|c|c|c|c|}
\hline 5 & $\begin{array}{l}\text { Dispora } \\
\text { budpar }\end{array}$ & $\begin{array}{l}\text { 2) } \\
\text { 3) } \\
4) \\
5)\end{array}$ & $\begin{array}{l}\text { Diklat Perencanaan Peraturan Perundang-Undangan sesuai } \\
\text { dengan PP } 59 \text { tahun } 2015 \\
\text { Bintek Penilaian Prestasi Kerja PNS dan Penyusunan SKP } \\
\text { Bintek Sistem Administrasi Kepegawaian } \\
\text { Diklat Database Komputer } \\
\text { Diklat 7DIH }\end{array}$ \\
\hline 6 & $\begin{array}{l}\text { Sekretariat } \\
\text { Dewan }\end{array}$ & $\begin{array}{l}\text { 2) } \\
\text { 3) } \\
\text { 4) } \\
5)\end{array}$ & $\begin{array}{l}\text { Bintek Penyusunan Pedoman dan Petunjuk di Bidang Penelitian, } \\
\text { Pengolahan Data Hukum dan Peraturan Perundang-Undangan } \\
\text { serta menyiapkan Rancangan Produk Hukum yang dihasilkan } \\
\text { DPRD } \\
\text { Diklat Kehumasan dan Keprotokolan } \\
\text { Bintek Tata Cara Penyusunan RKA \& DPA Instansi Pemerintahan } \\
\text { Bintek Pengelolaan Keuangan Anggaran } \\
\text { Bintek Tata Cara Penatausahaan \& Penyusunan Laporan } \\
\text { Pertanggungjawaban Bendahara serta Penyampaiannya }\end{array}$ \\
\hline
\end{tabular}

\begin{tabular}{|c|c|c|c|}
\hline 7 & Dinas PU & $\begin{array}{l}\text { 1) } \\
\text { 2) } \\
\text { 3) }\end{array}$ & $\begin{array}{l}\text { Diklat Pengawasan dan Pemeliharaan Jalan, Jembatan dan Trotoar } \\
\text { Perencanaan Teknis Drainase Perkotaan } \\
\text { Diklat Inti Satuan Kerja (PISK) Bidang Cipta Karya (Persyaratan } \\
\text { Lingkungan dan Air Minum) } \\
\text { Bintek Pemberdayaan Jasa Konstruksi } \\
\text { Diklat Perencanaan dan Pengendalian Tata Ruang Kota }\end{array}$ \\
\hline 8 & $\begin{array}{l}\text { Kantor } \\
\text { Perpustakaan } \\
\text { dan Arsip }\end{array}$ & $\begin{array}{l}\text { 1) } \\
\text { 3) } \\
\text { 4) } \\
\text { 5) }\end{array}$ & $\begin{array}{l}\text { Bintek Sistem Informasi Manajemen Barang dan Aset Daerah } \\
\text { Bintek Penghapusan Aset } \\
\text { Bintek Sistem Pengelolaan Barang Milik Daerah/Negara } \\
\text { Bintek Strategi dan Tata Cara serta Teknik Penilaian Aset Daerah } \\
\text { Bintek Sistem Administrasi Kepegawaian }\end{array}$ \\
\hline 9 & $\begin{array}{l}\text { Dinas } \\
\text { Kebersihan } \\
\text { dan } \\
\text { Pertamanan }\end{array}$ & $\begin{array}{l}\text { 1) } \\
\text { 2) } \\
\text { 3) } \\
\text { 5) }\end{array}$ & $\begin{array}{l}\text { Diklat Perencanaan Program Persampahan } \\
\text { Diklat Manajemen Pengelolaan Persampahan } \\
\text { Diklat Pengelolaan dan Pengendalian Anggaran } \\
\text { Diklat Kearsipan } \\
\text { Diklat Manajemen SDM }\end{array}$ \\
\hline 10 & $\begin{array}{l}\text { Bagian } \\
\text { Organisasi dan } \\
\text { Tata Laksana }\end{array}$ & $\begin{array}{l}\text { 1) } \\
\text { 2) } \\
\text { 4) } \\
\text { 5) }\end{array}$ & $\begin{array}{l}\text { Diklat Analisa Jabatan } \\
\text { Pelatihan ESQ } \\
\text { Diklat TND Elektronik } \\
\text { Diklat Penyusunan LKIP } \\
\text { Diklat Penyususnan SPM, SOP, SPD } \\
\end{array}$ \\
\hline 11 & DPPKA & $\begin{array}{l}\text { 3) } \\
\text { 4) } \\
\text { 5) }\end{array}$ & $\begin{array}{l}\text { Bintek Pengelolaan Pajak PBB dan BPHTB berdasarkan PDRD } \\
28 / 2009 \\
\text { Bintek Pengeololaan Potensi Pajak Daerah dan Tetribusi Daerah } \\
\text { untuk Pengangkatan PAD } \\
\text { Diklat Management of Training bagi pejabat bidang Pendapatan } \\
\text { Bintek Penyusunan Laporan Keuangan Instansi Daerah } \\
\text { Bintek akuntansi pelaporan dan pertanggungjawaban } \\
\text { pelaksanaan APBD }\end{array}$ \\
\hline 12 & $\begin{array}{l}\text { Kantor } \\
\text { Lingkungan } \\
\text { Hidup }\end{array}$ & $\begin{array}{l}\text { 1) } \\
\text { 2) }\end{array}$ & $\begin{array}{l}\text { Bintek sistem dan tatacara penghapusan asset } \\
\text { Bintek sistem informasi manajemen barang dan aset daerah } \\
\text { (simbada) } \\
\text { Bintek administrasi keuangan dan perencanaan bagi pengguna } \\
\text { anggaran, PPTK, PPK dan bendahara } \\
\text { Bintek kewajiban perpajakan bagi instansi pemerintah } \\
\text { Diklat fungsional dasar-dasar pengawasan lingkungan hidup }\end{array}$ \\
\hline
\end{tabular}




\begin{tabular}{|c|c|c|c|}
\hline 13 & Kecamatan & 1) & Diklat Monev \\
\hline & Prajurit Kulon & 2) & Diklat manajemen aparatur sipil negara didaerah \\
\hline & & 3) & Workshop pertanahan \\
\hline & & 4) & Bintek akuntansi pelaporan dan pertanggungjawaban \\
\hline & & & pelaksanaan APBD \\
\hline & & 5) & Bintek Sistem Administrasi Kepegawaian \\
\hline 14 & RSU Dr. & 1) & Diklat Bendahara Penerimaan \\
\hline & Wahidin & 2) & Pelatihan Aseptic dispensing bagi petugas TTK \\
\hline & Sudiro Husodo & 3) & Diklat Pengelolaan Keuangan \\
\hline & & 4) & Pelatihan Excellent Service \\
\hline & & 5) & Diklat Petugas Proteksi Radiasi \\
\hline 15 & Diskoperindag & 1) & Diklat Kemetrologian \\
\hline & & 2) & Diklat Manajemen Pengelolaan dan Pengendalian Program \\
\hline & & 3) & Diklat Manajemen Pengelolaan dan Pengendalian Keuangan SKPD \\
\hline & & 4) & Diklat Manajemen Organisasi Pemerintahan Daerah \\
\hline & & 5) & $\begin{array}{l}\text { Diklat Manajemen Pengelolaan dan Pengendalian Barang dan } \\
\text { Aset }\end{array}$ \\
\hline 16 & Disnaker & 1) & Bintek penilaian prestasi kerja PNS dan penyusunan SKP \\
\hline & & 2) & Bintek Sistem Penyusunan anggaran berbasis kinerja \\
\hline & & 3) & Bintek tata cara penyusunan RKA dan DPA instansi pemerintahan \\
\hline & & 4) & Bintek ASN sesuai dengan UU RI no 5 Tahun 2014 \\
\hline & & 5) & $\begin{array}{l}\text { Bintek pedoman penyusunan dan pengembalian Renja SKPD dan } \\
\text { RKPD }\end{array}$ \\
\hline
\end{tabular}

\section{KESIMPULAN}

Setiap Unit Kerja memiliki karakteristik masing-masing sesuai dengan tugas dan fungsinya. Pada level jabatan struktural pun juga memeiliki kebutuhan diklat yang dapat diusulkan secara individu sesuai pangkat dan jabatan. Usulan-usulan inilah yang dijadikan sebagai landasan dalam mengidentifikasikan kebutuhan diklat. Kebutuhan diklat yang dihasilkan dari kajian ini dapat dilihat dalam rekomendasi.

\section{DAFTAR RUJUKAN}

Adiputra, Pradana. 2011. Hubungan Kompetensi dengan Kinerja Pemeriksa Pajak Pada Kantor Pelayanan pajak Pratama di Badung Selatan. Universitas Pendidikan Ganesha.

Arep, H. I dan Tanjung. 2002. Manajemen Sumber daya Manusia. Jakarta: Universitas Trisakti.

Barthos, Basir. 1990. Manajemen Sumber Daya Manusia Suatu Pendekatan Makro. Jakarta: PT Bumi Aksara.

Brown, Judith. 2002. Training Needs Assessment: A Must for Developing an Effective Training Program. Public Personal Manaement. 31 (04). p.569-578.

Dessler, G. 2006. Manajemen Sumber Daya Manusia. Jakarta: PT Indeks

Emmyah. 2009. Pengaruh Kompetensi terhadap Kinerja Pegawai pada Politeknik Negeri Ujung Pandang. Program Magister Ilmu Administrasi. Makassar: STIA LAN.

Hafid, Firdaus. 2015. Pengembangan Kompetensi Pegawai Negeri Sipil Melalui Pendidikan dan Pelatihan. Diakses Online dalam http://makassar.lan.go.id/index.php/survei/publikasi/artikel/269pengembangan-kompetensi-pegawai-negeri-sipil-melalui-pendidikan-danpelatihan. Pada 5 Februari 2016.

Handoko, T. Hani. 2001. Manajemen Personalia Dan Sumber Daya Manusia. Edisi 2. Yogyakarta: BPFE-UGM. 
Hardjana, A. M. 2001. Training Sumberdaya Manusia yang Efektif. Yogyakarta: Kanisius. Hartawan, Tony. 2012. Menteri Azwar: Indonesia Krisis PNS yang Kompeten. Diakses onlinedalam http://nasional.tempo.co/read/news/2012/02/29/173387194/menteri-azwarindonesia-krisis-pns-yang-kompeten. Pada 5 Februari 2016

Hasibuan, H.S. Peningkatan Kompetensi PNS Melalui Diklat Administrasi Perkantoran. Hasibuan, Malayu. S.P. 2002. Manajemen Sumber Daya Manusia. Jakarta: Bumi Aksara. Helena AK, Marly. 2009. Hubungan Pendidikan dan Pelatihan dengan Kompetasi Pegawai Negeri Sipil di Bidang Pelayanan Publik (Studi pada Pelaksanaan Pendidikan dan Pelatihan Kepemimpinan Tingkat IV Angkatan Tahun V Tahun 2008 di Lingkungan Pemerintah Kabupaten Aceh Tamiang. Tesis. Medan. Fakultas Ilmu Sosial dan Ilmu Poltik Universitas Sumatera Utara.

Mangkunegara, A. P. 2003. Perencanaan dan Pengembangan Sumberdaya Manusia. Bandung: PT Refika Aditama.

Notoatmodjo, S. 2003. Pengembangan Sumberdaya Manusia. Jakarta: PT Rineka Cipta.

Panggabean, S. M. 2004. Manajemen Sumberdaya Manusia. Bogor: Ghalia Indonesia.

Prayoga, Ricky. 2015. Pakar: Permasalahan PNS adalah Kompetensi. Diakses online dalam http://www.antaranews.com/berita/494973/pakar-permasalahan-pns-adalahkompetensi. Pada 5 Februari 2016.

Rachmawati, I. K. 2008. Manajemen Sumber Daya Manusia. Yogyakarta: Andi

Rivai, E. dan Sagala, J. E. 2009. Manajemen Sumberdaya Manusia untuk Perusahaan. Jakarta: Rajawali Pers.

Simamora, H. 1997. Manajemen Sumberdaya Manusia. Edisi KEdua. Cetakan PErtama. STIE YPKN.

Sofiyandi, H. 2008. Manajemen Sumber Daya Manusia. Yogyakarta: Graha Ilmu.

Suwatno dan Rasto. 2003. Manajemen Perusahaan Suatu Pendekatan Operatif dan Sistem Informasi. Bandung: UPI.

Tunggal, Amin Widjaja. 1993. Manajemen: Suatu Pengantar. Jakarta: Rineka Cipta. 